\title{
Environmental crisis: towards an integrated approach
}

\section{The problem}

A supposed environmental crisis, includes a crisis of water, and has to be understood in a process of deconstruction of the common, resources or goods that should be of all, or at least enjoyed by all, and for several reasons are not being, this is the main issue we highlight here. There is an appropriation of these as goods or resources for the market. In the view of Capra et Mattei ${ }^{1}$, the notion of common, community is lost, or is being lost more and more in a process of commodification. In this case, the law is being more important in a complex arrangement, and the laws must rescue that sociability. In this way, it is necessary to reflect on the unfeasibility of a State based on the common, in line with the dynamics of nature reproduction. Therefore, it is in this context of commodification of environmental goods essential to life, that there is an environmental crisis potentiated in a process of climate change quite delicate, which is already causing disasters that force people to leave their territories and lack of water is also one of the elements in this process.

\section{Some pathways}

It seems that this dynamic reinforces a mechanization of the legislation itself that becomes incapable of establishing the essence of community life and the sense of enjoying common resources. There is a kind of social savagery, "my" water, my "fuel", my "air", my "soil", finally, resources that should be common and end up being appropriated in order to become a merchandise. Therefore, there is a need to move towards a systemic view of the management of these environmental goods. The legal order is still based on a mechanistic, Cartesian logic, which must perhaps migrate to a more systemic understanding. For this, it is fundamental to dive into the dynamics of nature's life

It seems that the evolution of nature for billions of years has something to teach humanity in terms of organization and gives indications of how to extract the needs for the survival of human beings. The interdependence between organisms reinforces the complexity of ecological processes. The question is how the law could influence, specifically the environmental law, requiring a profound transformation in the notion of what is nature in law.

In Boyd's understanding ${ }^{2}$ this systemic vision is fundamental to change the environmental law, for example, to the consolidation of an environmental protection system aimed at sustainable development. It's important to understand how the principles of nature organization are given, which would imply a high research load, and an interaction between the field of law and the field of the natural sciences. It seems that the most interesting possibility would be to seek a system of laws that would characterize the common.

This panorama shows the nuances of a hyper complex society, which is based on high consumption, accumulating pollutant residue, which does not have a proper place to deposit and ends up contaminating the soil, groundwater, oceans, air, in short, an effect

${ }^{1}$ Capra F, Mattei U. The Ecology of Law. Okland: BK; 2015.

${ }^{2}$ Boyd DR. The Rigths of Nature: A Legal Revolution that Could Save the World. Toronto: ECW Press; 2017.
Volume 3 Issue 3 - 2019

\author{
Jose Irivaldo Alves O Silva \\ School of Public Management, Federal University of Campina \\ Grande, Brazil
}

Correspondence: Jose Irivaldo Alves O Silva, Public Managemente Unit, Federal University of Campina Grande, Brazil,Email irivaldo.cdsa@gmail.com,prof.irivaldo@ufcg.edu.br

Received: April 26, 2019 | Published: May 15, 2019

chain that has repercussions for decades; hence the legislation still seems permissive in this phenomenon and the public managers, who implement the policies, are unprepared for changes, and without human resources prepared and without money to invest in technology in the environmental field.

What Capra et Mattei $^{3}$ propose is precisely a dialogue between law and ecology, as something essential for the change in survival of life in planet. Or as Leff ${ }^{4}$ points out to a necessary reappropriation of nature, in fact a re-signification of the nature for humanity, with the necessary transformation of meaning.

These issues become more complex in urban agglomerations, cities around the world increasing in size, population growing, a consolidated trend of more than $85 \%$ of the world population living in cities $^{5}$ faced with an extremely complex problem of survival in the community. This model being destroyed by an individualistic view of consumption of resources such water, which should be common, and which are serving to supply industrial parks and agribusiness.

There is a few understanding that we live in a condominium called Earth, that has limits, and must find ways to supply the population in a rational way. In this territory of the cities there are exactly several spatial scales that has repercussion in the local and regional planning, among them the metropolis and the hydrographic basin. These models of organization contradict exactly what is known as federation state, which would be that constitutional division in autonomous parts, which have self-management, for example the municipalities, states and federal district, headed by the Union, central government, that would give administrative uniformity to the whole, in the case of Brazil.

Inside the federative model, the metropolis has in its purpose sharing the management of resources, the management of environmental goods, among them water and, consequently, sanitary sewage, which are part of what is known as basic sanitation, this is extremely relevant because its management is strategic for environmental conservation, soil, aquifers, springs, rivers and seas.

${ }^{3}$ Capra F, Mattei U. The Ecology of Law. Okland: BK; 2015.

${ }^{4}$ Leff H. Racionalidade ambiental: a reapropriação social da natureza. Rio de Janeiro: Civilização Brasileira; 2006.

${ }^{5}$ Farias T, Correia AF. Considerações a respeito da edificação urbana às margens de rios: a lei 12.651/2012 (novo código florestal) e a competência legislativa municipal. In FERREIRA, O. A. V. A., GRAU NETO, W. Temas polêmicos do Novo Código Florestal. São Paulo: Migalhas; 2016. 
To return to the question of the environmental crisis, it must be considered taking into account the various fields of knowledge existing in a systemic way, there is a crisis whose effects are harmful especially for the most vulnerable population, see the process of climate change, for example, which, to a large extent, helps to increase environmental refugees, communities suffering from the effects of this process that no longer have access to water on a regular basis, have lost their territories, their land is no longer fertile, a real humanitarian catastrophe. So, it's necessary an International Law focused on an ecological matrix, an International Ecological Law.

There is a major global environmental crisis that isn't in line with a centralized model of law in an ordinary democratic state of law that does not take into account the complexity of these contemporary demands, advancing to an Ecological Law in the molds advocated by teachers Morato and Voigt ${ }^{6}$ the "web of life" ". So perhaps a solution would be an ecological analysis on the law, a systemic analysis.

We are facing an unprecedented crisis in mankind that has not yet become an effective public agenda, as we are soon thinking of signed protocols and treaties that have not become a reality in national law, followed by lengthy negotiations to persuade nations which further degrade the Planet. The Latin American constitutions sought to translate into their texts the need for a new look at the environment that goes beyond considering it as a set of resources, but as a complexity that needs urgent protection above human demands, already incorporating the real limitation of the planetary. If it could be questioned the effectiveness of those constitutions, it would be a lie a positive answer, because the international order is still based on an exploratory logic of natural resources. Therefore, a clearer and more honest view of the international, regional and local dynamics is needed.

This can be seen in sustainable development dream that wasn's fully realized yet. Although it should not be forgotten that progress

\footnotetext{
${ }^{6}$ Leite JRM, Silveira PG, Bettega B. O Estado de Direito para a natureza: fundamentos e conceitos. In Dinnebier, Flávia França (Org.). Estado de Direito Ecológico: Conceito, Conteúdo e Novas Dimensões para a Proteção da Natureza. São Paulo: Inst. O direito por um Planeta Verde; 2017; Voigt. C. Rule of Law for Nature: New Dimensios and Ideas in Environmental Law. Cambridge: Cambridge UP; 2013.

${ }^{7}$ Capra F, Mattei U. The Ecology of Law. Okland: BK; 2015.
}

has been made in discussions and in the construction of clean technologies, however, as pointed out earlier, commitments are still very fluid, very flexible, soft law, in which developed nations are still committed to achieving very small sustainability targets.

\section{Some main ecotargets}

Mistakenly for decades the environment was thought of in a fragmented way, which does not fit with the notion of contemporary complexity. Thinking in water, for example, it is known that the preservation of the river sources is fundamental for the existence of considerable stocks of water for the maintenance of life in cities and forests. These river sources are protected by the existence of vegetation preserved in the Areas of Permanent Preservation (APPs), therefore, in the hill slopes for example, being still fundamental the preservation of the ground, without ground there is no water. In addition, one must think in terms of large underground aquifers that need to be preserved in order to ensure their recharge.

\section{Conclusion}

"Water", is the main example, should be treated as "water" rather than as a resource, giving space for more complex and integrated discussions with the other elements of nature, not restraining the "water issue" to an eminently technical or sociotechnical solution, thinking of a participatory management model that adds social justice and ecological justice to a certain extent; and that it is inserted in a larger context that could be classified as "environmental crisis", in a integrated vision. This panorama of crisis, much more than marking a historical moment of human ripening, has as a greater meaning that the systems that make up the great Earth system is above its capacity to sustain the growing human demands and still detached from a vision of ecological justice and social justice.

\section{Acknowledgments}

None.

\section{Conflicts of interest}

The author declares that there are no conflicts of interest. 